\title{
Phase of Labor
}

National Cancer Institute

\section{Source}

National Cancer Institute. Phase of Labor. NCI Thesaurus. Code C92940.

The various distinct periods during the first stage of labor and childbirth; such as a latent, active or a transition phase. 